\title{
Overcoming resistance to bisphosphonates through the administration of alfacalcidol: results of a one-year, open follow-up study
}

\author{
János Gaál, Tamás Bender, József Varga, Irén Horváth, \\ Judit Kiss, Péter Somogyi, and Péter Surányi
}

János GAÁL MD, Ph.D. (correspondent), Irén HORVÁTH MD, Judit KISS MD, and Péter SURÁNYI MD., Ph.D.

'Kenézy Gyula' Hospital, Department of Rheumatology and Physical Therapy, H-4043 Debrecen, BartókBéla u. 2-26., e-mail: gaalja@freemail.hu, Tel: +36 30219 2021, Fax: +36 52511833

Tamás BENDER MD., Ph.D.

Polyclinic of the Hospitaller Brothers of St. John of God in Buda, Budapest, Hungary

József VARGA, Ph.D.

University of Debrecen, Department of Nuclear Medicine, Debrecen, Hungary

Péter SOMOGYI MD.

Semmelweis University, Faculty of Medicine, Department of Orthopaedics, Budapest, Hungary 


\section{Introduction}

Osteoporosis is a disorder that leads to enhanced bone fragility through a decrease in the mass as well as deterioration of the microarchitecture of bones. Owing to its high prevalence and negative impact on quality of life, osteoporosis is the third most important public health disorder (after malignancies and cardiovascular disease), afflicting 200 million people worldwide [1]. Oral bisphosphonates are routinely prescribed for treatment for patients with osteoporosis. Adequate calcium and vitamin D sufficiency of the body is essential for antiresorptive treatment to be effective. According to HoRváth et al., serum 25hydroxyvitamin $\mathrm{D}_{3}$ level is lower than normal in $40 \%$ of elderly nursing home residents, whereas data from BнAтTOA et al. reflect the same in $56.7 \%$ of postmenopausal women [2, 3]. Some studies demonstrated statistically significant reduction of fractures during five years of high dose (100 000 E every four months) treatment with vitamin $\mathrm{D}_{3}$ [4], but others not [57]. According to a recent study, in 8 to 25 per cent of osteoporotic patients, bone loss continues despite adequate treatment with bisphosphonates, administered in combination calcium and vitamin $\mathrm{D}_{3}$ supplementation [8]. A proportion of these patients may have functional hypovitaminosis D potentially resulting from insufficient intake (despite supplementation), impaired activation, genuine resistance to vitamin D3 or secondary hyperparathyroidism [9]. In the remainder, the cause underlying the lack of bisphosphonate effects is unknown.

In osteoporosis, genuine resistance to bisphosphonates is probably non-existent or may be considered extremely uncommon, at the least. In Paget's disease, by contrast, where therapy is aimed at achieving complete biochemical remission, resistance to bisphosphonates has been demonstrated by several researchers. The lack of a complete biochemical remission is regarded by some as the criterion for bisphosphonate resistance [10], whereas according to others [11], the latter is established by a lower than 50-per-cent decrease in serum alkaline phosphatase (AP) level. Notwithstanding the criteria, the prevalence of resistance varies with different bisphosphonates in the range between $83 \%$ (etidronate [10]) and $11 \%$ (zolendronate [12]).

According to additional, relevant evidence, the efficacy of activated analogues of vitamin D (alfacalcidol, calcitriol) in reducing bone fractures and increasing bone density is superior to that of native vitamin D. This has been demonstrated by several studies in various disease forms, i.e. in postmenopausal osteoporosis, as well as in osteoporosis related to inflammatory joint disease, or glucocorticoid therapy [13-16]. 
This study was intended to ascertain:

1. whether replacing vitamin $\mathrm{D}_{3}$ with alfacalcidol is followed by an increase in BMD (i.e. bisphosphonate resistance can be overcome) in patients not responding to treatment with a bisphosphonate administered in combination with supplemental calcium and conventional vitamin $\mathrm{D}_{3}$;

2. the incidence of hypovitaminosis $\mathrm{D}_{3}$ in the study population;

3. the changes occurring in biochemical markers of bone turnover during one year of treatment with alfacalcidol,

4. the frequency of adverse events associated with the use of alfacalcidol. 


\section{Patients and methods}

\section{Patients}

Seventy-six patients were enrolled into the study conducted between January 2006 and March 2007. The duration of follow-up was 12 months on average. Inclusion criteria were: diagnosed postmenopausal or senile osteoporosis (in females) or idiopathic osteoporosis in males, and greater than 3\% decrease in BMD - as demonstrated by axial DEXA - despite adequate treatment (vitamin $\mathrm{D}_{3}$ 400-1000 U/day, calcium $1000 \mathrm{mg} /$ day and alendronate $70 \mathrm{mg} /$ week) for a year or longer. Exclusion criteria comprised established secondary osteoporosis, other forms of calcipenic osteopathy, hypercalcaemia, and history of renal calculosis. The male-to-female ratio was 4:72; mean age of the study population was 70.5 $( \pm 8.2)$ years. Ten patients had a history of at least one prevalent vertebral or low-trauma peripheral fracture. The average serum 25-hydroxyvitamin D3 level was 72,2 $\pm 36,2 \mathrm{nmol} / \mathrm{l}$ at the starting and $74,1 \pm 34,0 \mathrm{nmol} / \mathrm{l}$ at the end of the study (the difference was not significant statistically). Below normal serum 25-hydroxyvitamin $\mathrm{D}_{3}$ level $(<75 \mathrm{nmol} / \mathrm{l})$ was found in 38 patients, along with elevated (>72 pg/ml) serum PTH level in 23 of these subjects. The mean glomerular filtration rate (GFR) was $85,3 \mathrm{ml} / \mathrm{min} / 1,73 \mathrm{~m}^{2}$ at baseline and 4 patients had GFR lower than $60 \mathrm{ml} / \mathrm{min} / 1,73 \mathrm{~m}^{2}$ at starting of the study, 2 of them had elevated serum PTH level. In the included patients, the average administered dose of D3 vitamin was $530 \mathrm{U} / \mathrm{day}$ along with $1000 \mathrm{mg}$ of calcium supplementation before the starting of the study.

\section{Study design}

During the follow-up period of one-year on average, control visits were scheduled at baseline and at 3-month intervals thereafter. At baseline, a detailed history (concomitant diseases, fractures, osteoporosis and risk factors) was recorded along with appraisal of clinical status by obtaining a lateral x-ray of the lumbosacral spine and performing a laboratory screen (ESR, CRP, CBC, serum calcium, phosphorus, BUN, creatinine, GOT, GPT, AP, albumin, osteocalcin, 25-hydroxyvitamin- $\mathrm{D}_{3}$, parathormon $[\mathrm{PTH}]$ levels, urinary calcium/creatinine [UCa/Cr] and deoxypyridinoline crosslinks/creatinine [D-Pyr/creatinine] ratios). Bone density was measured in both peripheral bones (DTX200) and in the axial skeleton (DEXA, Lunar DPX Pro) and BMD values obtained from the radius distal segment, as well as the means of the values measured in the $1^{\text {st }}$ through $4^{\text {th }}$ lumbar vertebrae were taken into account. Serum calcium level and urinary calcium/creatinine ratio were determined at control visits repeated at 3-month intervals. After one year, information was gathered on fractures and renal 
calculosis that had occurred during the follow-up period, as well as osteodensitometry, lumbosacral x-ray, and laboratory screen were repeated.

\section{Treatment protocol}

The pre-existing regimen of alendronate $70 \mathrm{mg}$ once per week was left unchanged, but conventional vitamin $\mathrm{D}_{3}$ and calcium treatment was replaced with $0.5 \mu \mathrm{g} / \mathrm{day}$ alfacalcidol (1 $\alpha$ hydroxvitamin $\mathrm{D}_{3}$ ). The calcium supplementation was stopped also.

\section{Endpoints}

The primary endpoint of the study was defined as the change measurable (by DEXA) in bone mineral density (BMD) of the forearm and of axial bones one year after the introduction of alfacalcidol treatment. Secondary endpoints included changes in clinical chemistry parameters (serum calcium, phosphorus, and alkaline phosphatase levels), biochemical markers of bone turnover (serum osteocalcin, $\mathrm{PTH}$, urinary $\mathrm{D}-\mathrm{Pyr} /$ creatinine), $\mathrm{UCa} / \mathrm{Cr}$ ratio determined in first-voided morning urine, treatment-emergent adverse reactions, and osteoporotic fractures that occur during follow-up.

\section{Statistical analysis}

The differences between the values of study parameters (BMD; serum Ca, P, AP, osteocalcin, PTH levels; urinary D-Pyr/creatinine and $\mathrm{UCa} / \mathrm{Cr}$ ratios) determined at two time points were analysed using the SPSS 15.0 software package. First, the normality of differences was checked with the Kolmogorov-Smirnov test (normal distribution would allow performing a parametric [ $t$ or $d]$ test). The differences between the paired values of all nine variables were significantly different from the normal distribution $(p<0.01$ for $\mathrm{UCa} / \mathrm{Cr}$ and $p<0.001$ for the rest). As the data were unsuitable for analysis with the $t$-test, non-parametric Wilcoxon signed-rank test was performed to check the uniformity of repeated measurements. (This method is a non-parametric alternative to performing a paired $t$-test.)

\section{Results}

a) Changes in BMD during follow-up

The median of changes as well as the minimal and maximal changes are summarised in Table 1. 


\begin{tabular}{|l|c|c|c|c|}
\hline & Unit & Median & Minimum & Maximum \\
\hline \hline Se Calcium & $\mathrm{mmol} / \mathrm{l}$ & $\mathbf{0 . 0 6}$ & -0.09 & 1.13 \\
\hline Se Phosphate & $\mathrm{mmol} / \mathrm{l}$ & $\mathbf{- 0 . 0 5}$ & -0.49 & 0.3 \\
\hline Alkaline phosphatase & $\mathrm{U} / \mathrm{l}$ & $\mathbf{- 1 3}$ & -46 & 287 \\
\hline Parathormone & $\mathrm{pg} / \mathrm{ml}$ & $\mathbf{- 1 0 . 7}$ & -150 & 22.5 \\
\hline Urinary Ca/creatinine & & $\mathbf{0 . 1}$ & -0.32 & 0.49 \\
\hline Osteocalcin & $\mathrm{ng} / \mathrm{ml}$ & $\mathbf{- 0 . 4}$ & -5.8 & 4.2 \\
\hline $\begin{array}{l}\text { BMD of forearm } \\
\text { BMD of lumbar 1-4 }\end{array}$ & $\mathrm{g} / \mathrm{cm}^{2}$ & $\mathbf{0 . 0 0 7}$ & -0.011 & 0.039 \\
\hline $\begin{array}{l}\text { BMrtebrae } \\
\text { Relative change of forearm }\end{array}$ & $\%$ & $\mathbf{0 . 0 1 2}$ & -0.998 & 0.116 \\
\hline $\begin{array}{l}\text { BMD } \\
\text { Belative change of lumbar }\end{array}$ & $\%$ & $\mathbf{2 . 1 8}$ & -3.5 & 16.3 \\
\hline $\begin{array}{l}\text { Deoxypyridinoline } \\
\text { crossinks/creatinine }\end{array}$ & $\mathbf{1 . 3 8}$ & -11.3 & 15.8 \\
\hline
\end{tabular}

Table 1: Median, minimal and maximal changes in various parameters as a result of treatment

After treatment for $396,5 \pm 21,3$ days with alendronate - with no change in the original dosage regimen of $70 \mathrm{mg} /$ week, but - in combination with $0.5 \mu \mathrm{g} /$ day alfacalcidol instead of the previously prescribed conventional vitamin $\mathrm{D}_{3}$ (administered with calcium), we observed the following changes (median values): forearm BMD increased by $0.007 \mathrm{~g} / \mathrm{cm}^{2}$, and lumbar $\left(\mathrm{L}_{1-4}\right)$ BMD increased by $0.012 \mathrm{~g} / \mathrm{cm}^{2}$. The changes in T-scores showed rather high scatter. The relative changes in BMD values were $2.18 \%$ and $1.38 \%$ for the forearm and lumbar vertebrae, respectively. BMD changes that have occurred during one-year follow-up are shown in Figure 1. Box and whiskers plots are summarizing the median, quartiles, and extreme values. The box represents the interquartile range which contains the $50 \%$ of values. 
The whiskers are lines that extend from the box to the highest and lowest values, excluding outliers. A line across the box indicates the median.

Compared to baseline values, densitometry results (both BMD values and T-scores) obtained after one-year treatment revealed statistically significant improvement in both regions (Wilcoxon's signed rank test, $p<0.001$ ).

\section{b) Changes in clinical chemistry parameters}

At baseline, mean serum calcium level was $2.34( \pm 0.106) \mathrm{mmol} / \mathrm{l}$, phosphorus level was 1.18 $( \pm 0.169) \mathrm{mmol} / \mathrm{l}$, and $\mathrm{UCa} / \mathrm{Cr}$ ratio measured in first-voided morning urine was $0.25( \pm 0.161)$. After one year of treatment, serum calcium level increased by $0.06 \mathrm{mmol} / \mathrm{l}$ (median), while serum phosphorus level decreased by $0.05 \mathrm{mmol} / \mathrm{l}$. Urinary $\mathrm{Ca}$ to creatinine ratio measured in first-voided morning urine increased by 0.1 (median). All these changes were significant (Wilcoxon's signed rank test, $\mathrm{p}<0.001$ ) (see Figure 2). The decline of serum alkaline phosphatase level over the follow-up period by a median of $13 \mathrm{U} / \mathrm{l}$ was also significant, but clinically not relevant (see Figure 3).

\section{c) Changes in biochemical markers of bone turnover}

Changes in serum parathormone (PTH) level were as expected. At baseline, elevated PTH was ascertained in 32 patients; this number decreased to 16 during the one-year follow-up. The median change in serum PTH level was significantly lower one year later (median change: $-10.7 \mathrm{pg} / \mathrm{ml}$ ) (Figure 3). Serum osteocalcin level decreased by $0.4 \mathrm{ng} / \mathrm{ml}$ (median) after treatment; this was accompanied by a decrease in the D-Pyr/creatinine ratio by 0.2 $\mathrm{nmol} / \mathrm{mmol}(p<0,001)$ (Figure 3). Although the changes showed high scatter, they proved to be highly significant (Wilcoxon's signed rank test, $p<0.001$ ). The ranges of relative changes expressed as percentages of the base values for all parameters (Figure 4).

\section{d) Adverse events}

Mild hypercalcaemia (serum calcium level $<3 \mathrm{mmol} / \mathrm{l}$ ) was observed in 3 patients; no other clinically relevant adverse reactions were seen. There was no significant increase in urinary calcium based on alendronate therapy.

\section{e) New fractures}

As stated above, ten patients had a history of at least one prevalent vertebral or low-trauma peripheral fracture at starting of the study. Four new vertebral and two peripheral (wrist) 
fractures were recorded during follow up. Two of the vertebral fractures were sustained by patients with a prevalent vertebral fracture.

\section{Discussion}

Some data from the literature suggest that activated vitamin D derivatives (alfacalcidol, calcitriol), also called D-hormone analogs, are superior to conventional vitamin D, as regards the mitigation of fracture risk. In their meta-analysis of 33 clinical studies, RICHY et al. found a 13.4-per-cent (delta RD, 95\% CI 7.7-19.8) reduction of fracture risk during the use of activated vitamin $\mathrm{D}_{3}$ derivatives, compared to a mere 6\% (delta RDi, 95\% CI 1-12) accomplished by treatment with conventional vitamin D3 [ 13]. The rate difference (RD) was statistically significant (ANOVA-1; P<0.001) RINGE et al. studied the changes of BMD and bone fractures in patients with glucocorticoid-induced osteoporosis, over 3 years of treatment with either alfacalcidol or vitamin $\mathrm{D}_{3}$ - both administered with calcium supplementation of $500 \mathrm{mg}$ daily. Changes in the BMD of the lumbar spine were $2.4 \%$ vs. $-0.8 \%(p<0.0001)$, and of the femoral neck $1.2 \%$ vs. $0.8 \%$ ( $p<0.006)$, respectively. The proportion of patients who have sustained at least one new vertebral fracture was $9.7 \%$ in the alfacalcidol and $24.8 \%$ in the control group (risk reduction: $0.61, p=0.005$ ), whereas the proportions of patients with at least one new non-vertebral fracture were $15 \% v s .25 \%$ (risk reduction: $0.41, p=0.08$ ). Taking the occurrence of any type of incident fractures into account, the above proportions were $19.4 \%$ vs. $40.6 \%$, respectively (risk reduction: $0.52, p<0.001$ ) [14].

During the AAC study published in 2007, 30-30 patients were randomised into either of the following 3 treatment arms: a) alfacalcidol $1 \mu \mathrm{g}+$ calcium $500 \mathrm{mg} / \mathrm{day} ; b$ ) alendronate $70 \mathrm{mg} /$ week + calcium $1000 \mathrm{mg} / \mathrm{day}$ + vitamin $\mathrm{D}_{3} 1000 \mathrm{IU} / \mathrm{day} ;$ c) alendronate $70 \mathrm{mg} / \mathrm{week}+$ calcium $500 \mathrm{mg} /$ day + alfacalcidol $1 \mu \mathrm{g} /$ day. During the 2 years of follow up, bone density of the lumbar spine and of the total hip increased by $3 \% / 1.5 \%, 5.4 \% / 2.4 \%$, and $9.6 \% / 3.8 \%$, respectively. The magnitude of changes observed in patients treated with alendronate + alfacalcidol + calcium was significantly greater than of those seen in the other two groups ( $p<0.0001$ for lumbar BMD and $p<0.0002$ for femur BMD). The number of new osteoporotic (vertebral + non-vertebral) fractures occurring over 2 years of treatment in the three treatment groups was 9,10, and 2, respectively - this finding is also in support of the favourable effect of alfacalcidol and especially of the combination of alendronate + alfacalcidol on fracture prevention [16].

As suggested by several studies, administering antiresorptive agents (e.g. bisphosphonates) with activated vitamin $\mathrm{D}_{3}$ derivatives may increase the success of therapy. The beneficial 
effects of alfacalcidol on intestinal calcium absorption, osteoid mineralization, muscle function and motor coordination, serum PTH level, and the risk of falls may substantially enhance the efficacy of treatment with bisphosphonates [17-18].

The anabolic effect of alfacalcidol on bone is supported also by in vivo and in vitro data. Under the effect of alfacalcidol, osteoblasts have been shown to release various growth factors (TGF- $\beta$, IGF-1 and -2, bone morphogenetic proteins [BMPs], bone matrix proteins [collagen I, osteocalcin, osteopontin]) and thereby counterbalance the reduction of bone turnover during treatment with bisphosphonates [18-21]. This osteoanabolic effect of alfacalcidol administered in combination with alendronate has been demonstrated by several studies [21-24].

Our study was conducted on patients whose bone density was declining despite adequate treatment with a bisphosphonate and supplementation of calcium plus conventional vitamin $\mathrm{D}_{3}$ since a year at least. Patients with renal impairment or secondary osteoporosis were not allowed to participate in the study. Notwithstanding this, the study population included a substantial number of patients with decreased serum 25-hydroxyvitamin $\mathrm{D}_{3}$ levels $(\mathrm{n}=38)$, accompanied by higher than normal serum PTH level $(n=23)$. This might suggest a potential relationship between resistance to bisphosphonates and the level of vitamin $\mathrm{D}_{3}$ insufficiency and the increase of serum PTH. Persistence of secondary hyperparathyroidism reduces BMD response to alendronate in older women with osteoporosis [9]. The improvement of the biochemical markers of bone turnover and increasing BMD indicate that patients apparently resistant to treatment with a bisphosphonate plus supplementation with calcium and conventional vitamin $\mathrm{D}_{3}$ are more likely to benefit from combination therapy with a bisphosphonate and alfacalcidol [9]. The enhanced efficacy of alendronate and alfacalcidol in combination is probably related to the synergism between the considerably different modes of action of the two components. In particular, the antiresorptive effect of alendronate is favourably supplemented by the mitigation of osteoclastogenesis [23, 25] and reduction of serum PTH level, along with the stimulation of osteoblast activity [21], improvement of bone quality [15,23] and the microarchitecture of trabecular bone by alfacalcidol [23]- which also enhances muscle strength and thereby activates the 'mechanostat' function of the skeleton [18]. The whole array of these effects might explain the outstanding effect on bones [17-18, 24]. Further elucidation of these mechanisms would require large-scale studies with fracture endpoints, defined in addition to monitoring changes in bone density. 
Although the lack of a control group may be considered a potential flaw of this study, the inclusion of untreated patients losing more than 3 per-cent of their bone density each year would have been ethically questionable at the least.

\section{Conclusion}

As shown by the results of this study, patients whose bone density decreases inexorably despite adequate treatment with alendronate and supplemental calcium and vitamin $\mathrm{D}_{3}$ might benefit from a combined treatment of alendronate with alfacalcidol. The latter combination accomplished significant increase of BMD along with improvement of the biochemical markers of bone turnover, but without any substantial increase in the incidence of adverse effects.

\section{References}

1. NIH Consensus Development Panel on Osteoporosis Prevention, Diagnosis and Therapy (2001) JAMA, 285:785-95 Medline doi:10.1001/jama.285.6.785

2. Horváth Cs, Novothny Gy, Mészáros Sz, Lakatos P, Szűcs J.(1998) A D-vitamin-hiány szerepe a gondozóintézetben ápolt betegek osteopeniájában. Ca és Csont 1:S10-16 [in Hungarian]

3. Bhattoa HP, Bettembuk P, Ganacharya S, Balogh A. (2004) Prevalence and seasonal variation of hypovitaminosis $\mathrm{D}$ and its relationship to bone metabolism in community dwelling postmenopausal Hungarian women. Osteoporos Int Jun;15(6):447-51

4. Trivedi DP, Doll R, Khaw KT. (2003) Effect of four monthly oral vitamin $\mathrm{D}_{3}$ (cholecalciferol) supplementation on fractures and mortality in men and women living in the community: randomised double blind controlled trial. BMJ Mar 1;326(7387):469

5. Law M, Withers H, Morris J, Anderson F (2006) Vitamin D supplementation and the prevention of fractures and falls: results of a randomised trial in elderly people in residential accommodation. Age Ageing 35:482-486 Medline. doi:10.1093/ageing/afj080

6. Lyons RA, Johansen A, Brophy S, Newcombe RG, Phillips CJ, Lervy B, Evans R, Wareham K, Stone MD (2007) Preventing fractures among older people living in institutional care: a pragmatic randomised double blind placebo controlled trial of vitamin D supplementation. Osteoporos Int 18:811-818 Medline. doi:10.1007/s00198-006-0309-5

7. Smith H, Anderson F, Raphael H, Maslin P, Crozier S, Cooper C (2007) Effect of annual intramuscular vitamin D on fracture risk in elderly men and women - a population-based, randomised, double-blind, placebo-controlled trial. Rheumatology 46:1852-1857 Medline. doi:10.1093/rheumatology//kem240 
8. Shebba AI (2008) Significance of a decline in bone mineral density while receiving oral bisphosphonate treatment. Clin Ther 30(3):443-452 Medline. doi:10.1016/j.clinthera.2008.03.008

9. Barone A, Giusti A, Pioli G, Girasole G, Razzano M, Pizzonia M, Palummeri E, Bianchi G (2007) Secondary Hyperparathyroidism Due to Hypovitaminosis D Affects Bone Mineral Density Response to Alendronate in Elderly Women with Osteoporosis: A Randomised Controlled Trial. J Am Geriatr Soc 55:752-757 Medline. doi:10.1111/j.1532$\underline{5415.2007 .01161 . x}$

10. Joshua F, Epstein M, Major G. (2003) Bisphosphonate resistance in Paget's disease of bone. Arthritis Rheum Aug;48(8):2321-3

11. Gutteridge DH, Ward LC, Stewart GO, Retallack RW, Will RK, Prince RL et al. (1999) Paget's disease: acquired resistance to one aminobisphosphonate with retained response to another. J Bone Miner Res Oct;14 Suppl 2:79-84

12. Siris ES, Lyles KW, Singer FR, Meunier PJ (2006) Medical management of Paget's disease of bone: indications for treatment and review of current therapies. J Bone Miner Res Dec;21 Suppl 2:P94-8

13. Richy F, Schacht E, Bruyere O, Ethgen O, Gourlay M, Reginster JY. (2005)Vitamin D analogs versus native vitamin $\mathrm{D}$ in preventing bone loss and osteoporosis-related fractures: a comparative meta-analysis. Calcif Tissue Int Mar;76(3):176-186

14. Ringe JD, Faber H, Fahramand P, Schacht E. (2005) Alfacalcidol versus plain vitamin D in the treatment of glucocorticoid/inflammation-induced osteoporosis.J Rheumatol Suppl. Sep; 76:33-40

15. Shiraishi A, Higashi S, Ohkawa H, Kubodera N, Hirasawa T, Ezawa I, Ikeda K, Ogata E (1999) The advantage of alfacalcidol over vitamin D in the treatment of osteoporosis. Calcif Tissue Int 65:311-316 Medline. doi:10.1007/s002239900704

16. Ringe JD, Farahmand P, Schacht E, Rozehnal A. (2007) Superiority of a combined treatment of Alendronate and Alfacalcidol compared to the combination of Alendronate and plain vitamin D or Alfacalcidol alone in established postmenopausal or male osteoporosis (AAC-Trial). Rheumatol Int Mar;27(5):425-34

17. Ringe JD, Schacht E.(2007) Improving the outcome of established therapies for osteoporosis by adding the active D-hormone analog alfacalcidol. Rheumatol Int Dec;28(2):103-11

18. Schacht E, Richy F, Reginster JY (2005) The therapeutic effects of alfacalcidol on bone strength, muscle metabolism and prevention of falls and fractures. J Musculoskelet Neuronal Interact 5(3):273-284 Medline.

19. Iwamoto J, Takeda T, Sato Y, Uzawa M (2007) Comparison of the effect of alendronate on lumbar bone mineral density and bone turnover in men and postmenopausal women with osteoporosis. Clin Rheumatol 26:161-167 Medline. doi:10.1007/s10067-006-0252-z

20. Greenspan SL, Resnick NM, Parker RA (2005) Early changes in biochemical markers of bone turnover are associated with long-term changes in bone mineral density in elderly women on alendronate, hormone replacement therapy, or combination therapy: a threeyear, double-blind, placebo-controlled, randomized clinical trial. J Clin Endocrinol Metab 90:2762-2767 Medline. doi:10.1210/jc.2004-1091 
21. Reszka AA, Pun S, Rodan GA, Freedman LP, Kimmel DB (2004) Bone anabolic effects of 1,25(OH)2 Vitamin D3 are detected only in the presence of a powerful antiresorptive. $\mathrm{J}$ Bone Miner Res 19:S483.

22. Erben RG, Mosekilde L, Thomsen JS, Weber K, Stahr K, Leyshon A, Smith SY, Phipps R (2002) Prevention of bone loss in ovariectomized rats by combined treatment with risedronate and 1·,25-dihydroxyvitamin D3. J Bone Miner Res 17:1498-1511 Medline. doi:10.1359/jbmr.2002.17.8.1498

23. Ito M, Azuma Y, Takagi H, Komoriya K, Ohta T, Kawaguchi H (2002) Curative effect of combined treatment with alendronate and 1- $\alpha-$-Hydroxyvitamin D3 on bone loss by ovariectomy in aged rats. Jpn J Pharmacol 89:255-266 Medline. doi:10.1254/jip.89.255

24. Schacht E, Dukas L, Richy F. (2007) Combined therapies in osteoporosis: bisphosphonates and vitamin D-hormone analogs. J Musculoskelet Neuronal Interact. Apr-Jun;7(2):174-84

25. Shibata T, Shiraishi A, Sato T, Masaki T, Masada A, Hishiya A, Ishikura N, Higashi S, Ushida Y, Saito MO, Ito M, Ogata E, Watanabe K, Ikeda K (2002) Vitamin D hormone inhibits osteoclastogenesis in vivo by decreasing the pool of osteoclast precursors in bone marrow. J Bone Miner Res 17:622-629 Medline. doi:10.1359/jbmr.2002.17.4.622 


\section{Figure legends}

Figure 1. The changes of BMD during follow-up. Box and whiskers plots are summarizing the median, quartiles, and extreme values.

Figure 2. Changes of serum calcium and phosphorus levels, as well as of $\mathrm{UCa} /$ creatinine ratio during the study.

Figure 3. The change of serum alkaline phosphatase activity (U/l), parathormone level ( $\mathrm{pg} / \mathrm{ml})$, osteocalcin level ( $\mathrm{ng} / \mathrm{ml})$ and of urinary deoxypirydinoline crosslinks/creatinine (D-Pyr/creatinine, $\mathrm{nmol} / \mathrm{mmol}$ ) by the end of the follow-up.

Figure 4. The ranges of relative changes expressed as percentages of the base values for all parameters. 

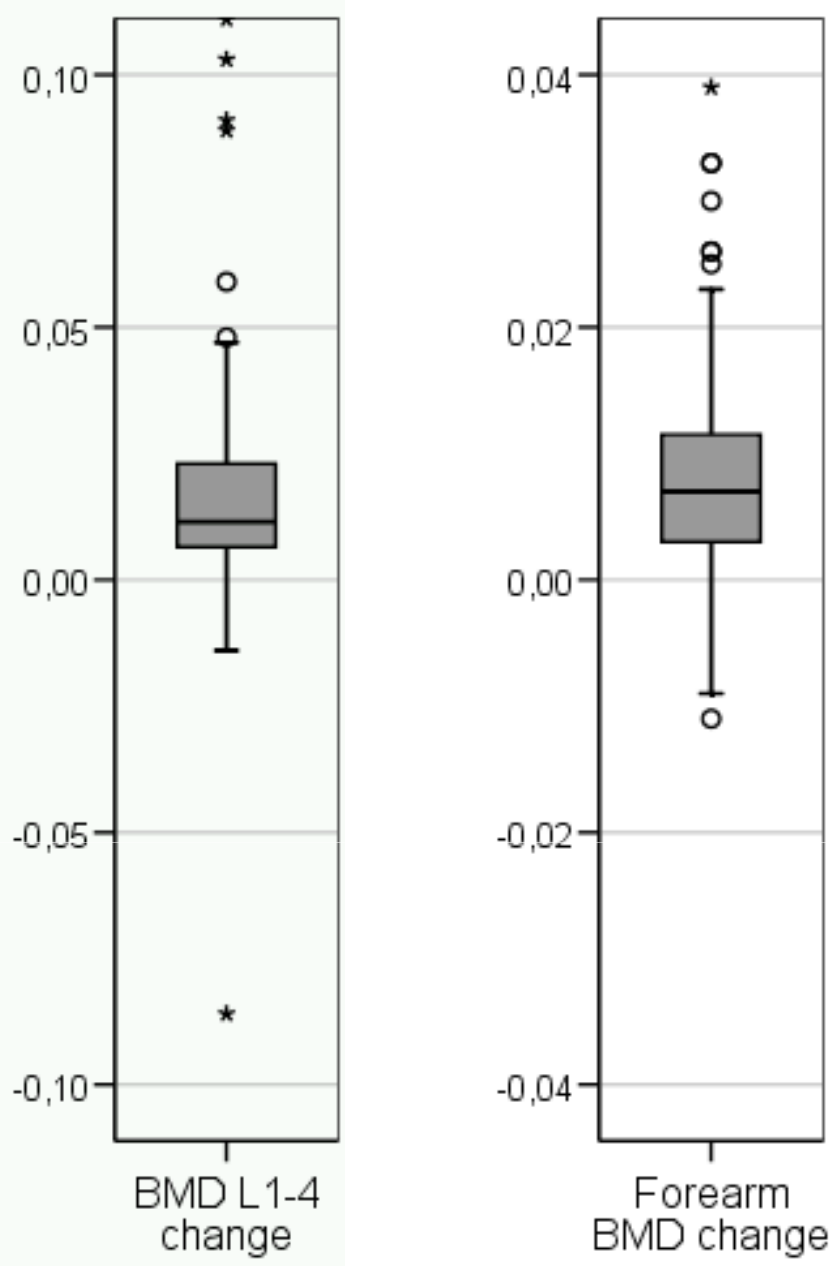

Figure 1. The changes of BMD during follow-up $\left(\mathrm{g} / \mathrm{cm}^{2}\right)$. 

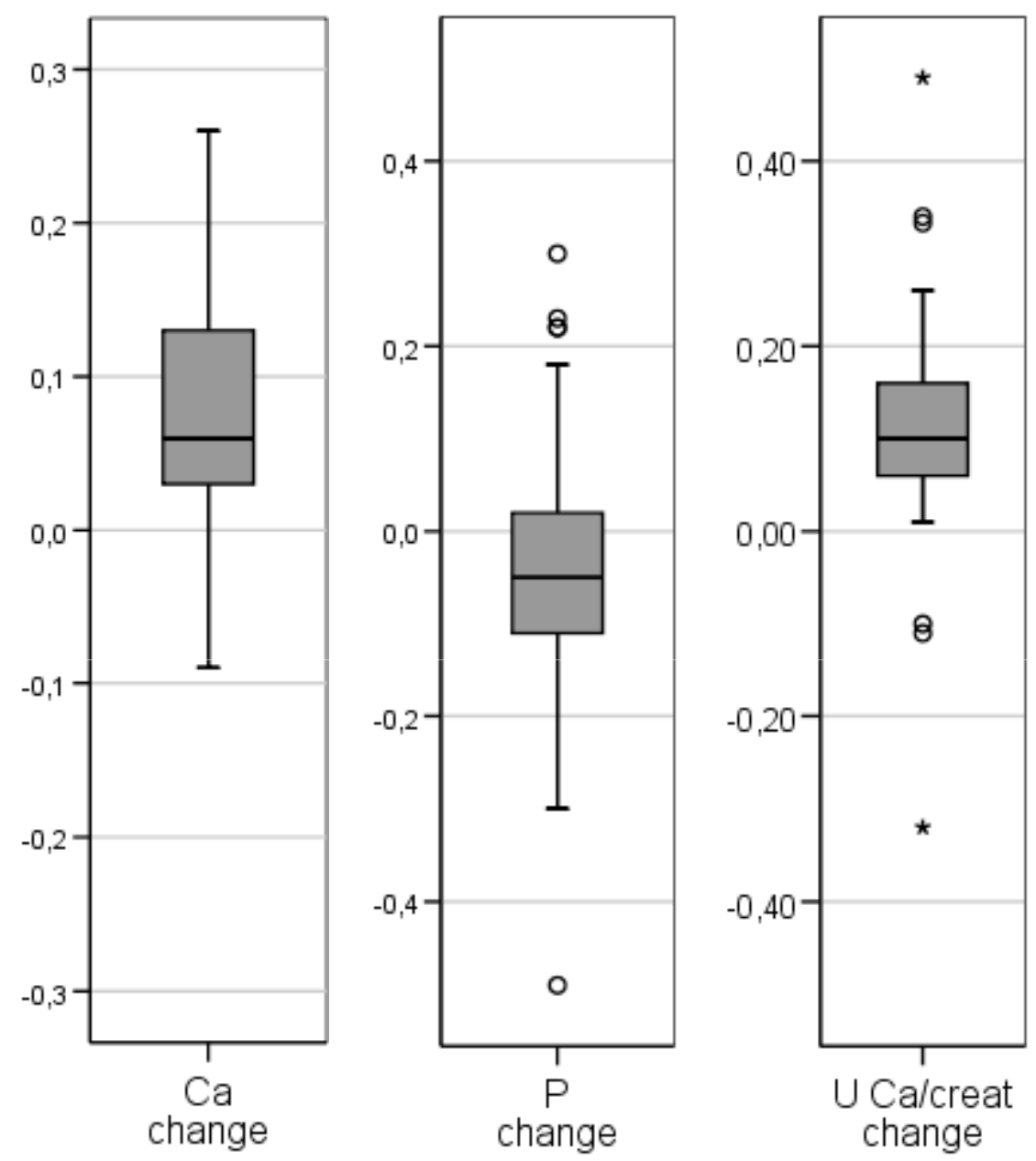

Figure 2. Changes of serum calcium and phosphorus levels (mmol/l), as well as of UCa/creatinine ratio during the study. 

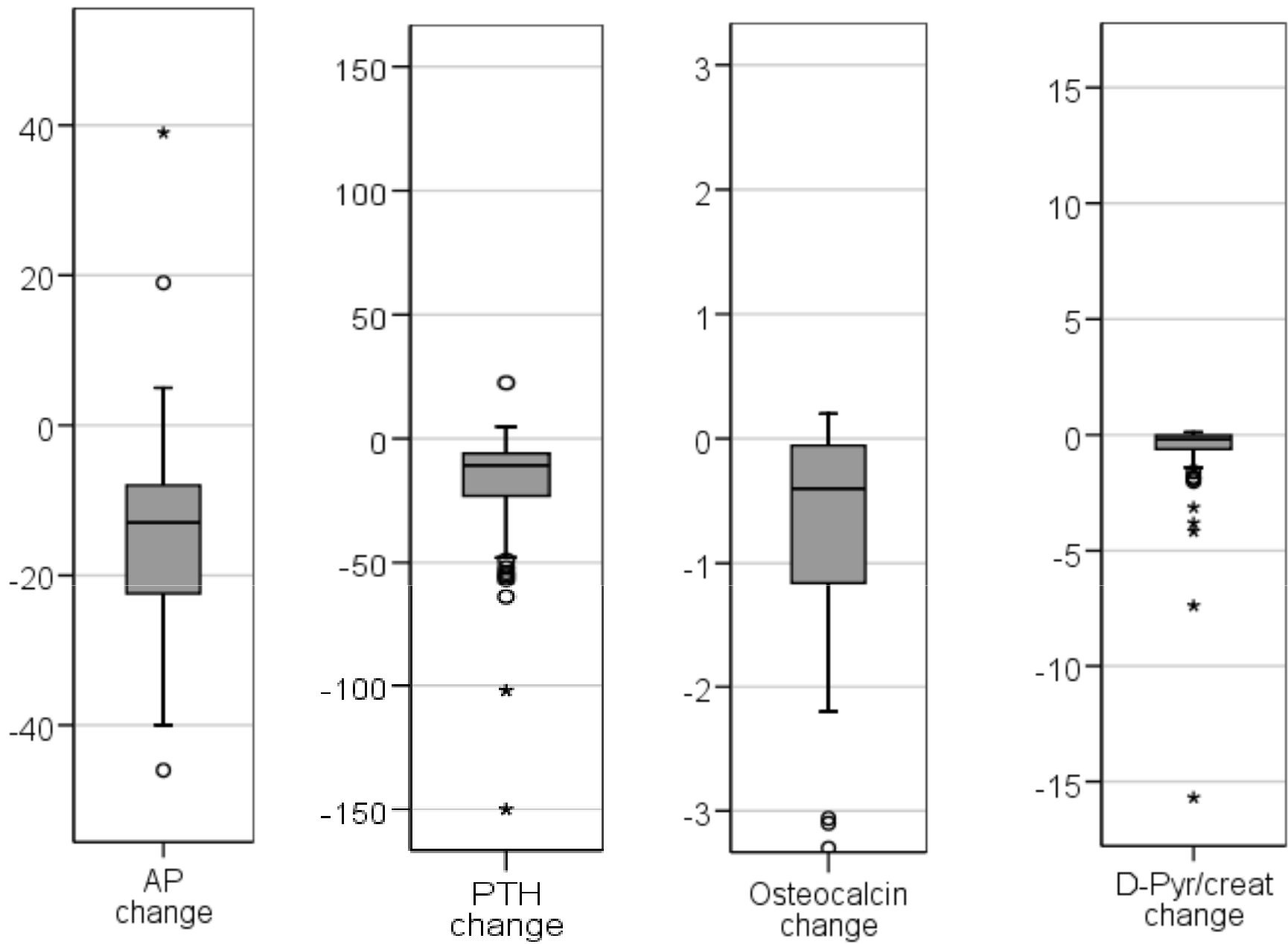

Figure 3. The change of serum alkaline phosphatase activity (U/l), parathormone level (pg/ml), osteocalcin level (ng/ml) and of urinary deoxypirydinoline crosslinks/creatinine (D-Pyr/creatinine, $\mathrm{nmol} / \mathrm{mmol}$ ) by the end of the follow-up. 


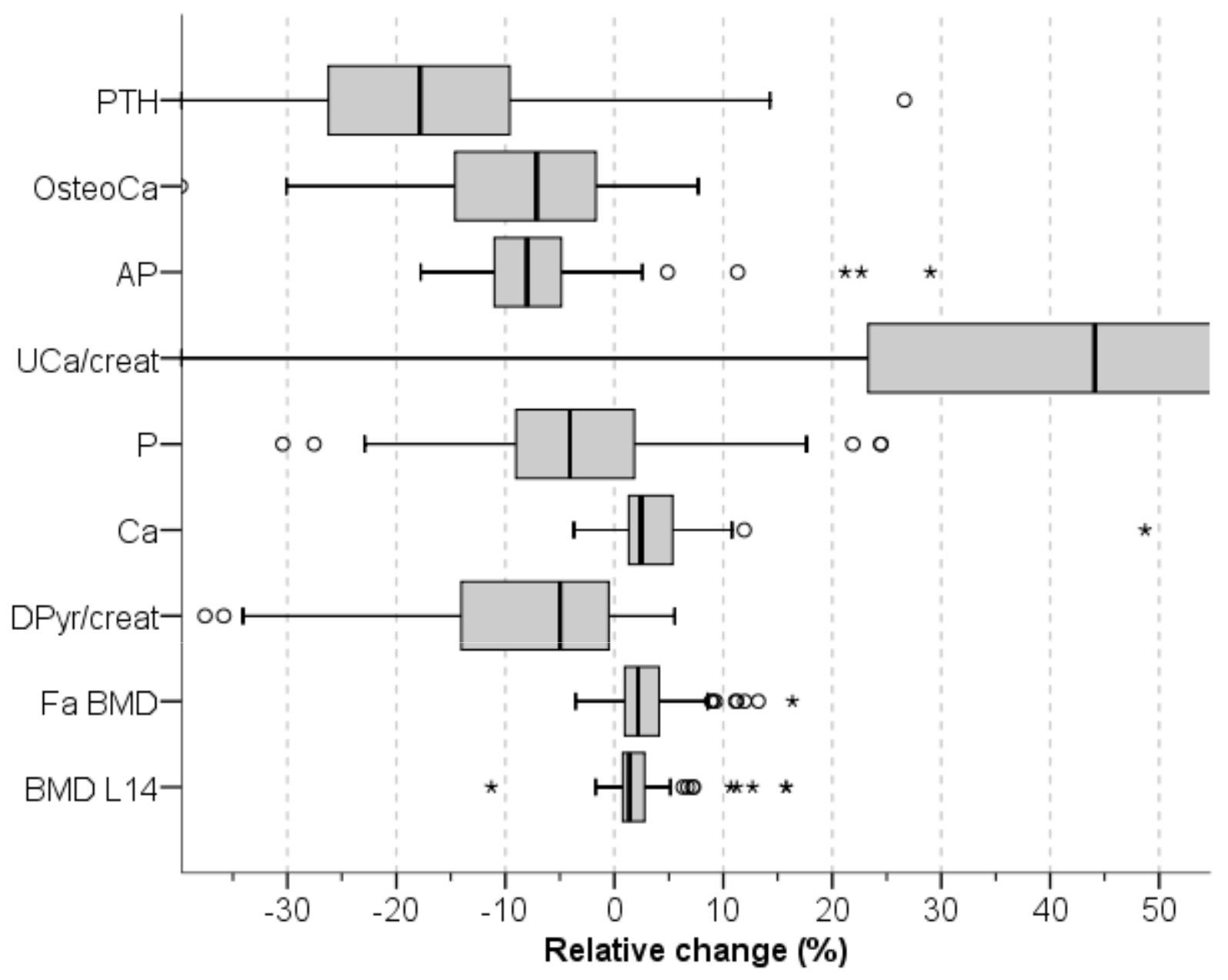

Figure 6. The ranges of relative changes expressed as percentages of the base values for all parameters. 